\title{
Front Matter: Volume 10007
}

, "Front Matter: Volume 10007," Proc. SPIE 10007, High-Performance Computing in Geoscience and Remote Sensing VI, 1000701 (14 December 2016); doi: 10.1117/12.2264939

SPIE. Event: SPIE Remote Sensing, 2016, Edinburgh, United Kingdom 




\title{
High-Performance Computing in Geoscience and Remote Sensing VI
}

\author{
Bormin Huang \\ Sebastián López \\ Zhensen Wu \\ Jose M. Nascimento \\ Jun Li \\ Valeriy V. Strotov \\ Editors
}

\section{September 2016 \\ Edinburgh, United Kingdom}

Sponsored by

SPIE

\section{Cooperating Organisations}

Innovation Centre for Sensor and Imaging Systems (United Kingdom) · ADS Scotland (United Kingdom) · The Knowledge Transfer Network (United Kingdom) · Visit Scotland (United Kingdom) · European Regional Development Fund (Belgium) · Technology Scotland (United Kingdom) · European Association of Remote Sensing Companies (Belgium) - European Association of Remote Sensing Laboratories (Germany) - The British Association of Remote Sensing Companies (United Kingdom) · Remote Sensing \& Photogrammetry Society (United Kingdom)

Published by

SPIE

Volume 10007 
The papers in this volume were part of the technical conference cited on the cover and title page. Papers were selected and subject to review by the editors and conference program committee. Some conference presentations may not be available for publication. Additional papers and presentation recordings may be available online in the SPIE Digital Library at SPIEDigitallibrary.org.

The papers reflect the work and thoughts of the authors and are published herein as submitted. The publisher is not responsible for the validity of the information or for any outcomes resulting from reliance thereon.

Please use the following format to cite material from these proceedings:

Author(s), "Title of Paper," in High-Performance Computing in Geoscience and Remote Sensing VI, edited by Bormin Huang, Sebastián López, Zhensen Wu, Jose M. Nascimento, Jun Li, Valeriy V. Strotov, Proceedings of SPIE Vol. 10007 (SPIE, Bellingham, WA, 2016) Seven-digit Article CID Number.

ISSN: 0277-786X

ISSN: 1996-756X (electronic)

ISBN: 9781510604186

ISBN: 9781510604193 (electronic)

Published by

SPIE

P.O. Box 10, Bellingham, Washington 98227-0010 USA

Telephone +1 3606763290 (Pacific Time) · Fax +1 3606471445

SPIE.org

Copyright () 2016, Society of Photo-Optical Instrumentation Engineers.

Copying of material in this book for internal or personal use, or for the internal or personal use of specific clients, beyond the fair use provisions granted by the U.S. Copyright Law is authorized by SPIE subject to payment of copying fees. The Transactional Reporting Service base fee for this volume is $\$ 18.00$ per article (or portion thereof), which should be paid directly to the Copyright Clearance Center (CCC), 222 Rosewood Drive, Danvers, MA 01923. Payment may also be made electronically through CCC Online at copyright.com. Other copying for republication, resale, advertising or promotion, or any form of systematic or multiple reproduction of any material in this book is prohibited except with permission in writing from the publisher. The CCC fee code is 0277-786X/16/\$18.00.

Printed in the United States of America.

Publication of record for individual papers is online in the SPIE Digital Library.

\section{SPIE. DIGITAL}

Paper Numbering: Proceedings of SPIE follow an e-First publication model. A unique citation identifier (CID) number is assigned to each article at the time of publication. Utilization of CIDs allows articles to be fully citable as soon as they are published online, and connects the same identifier to all online and print versions of the publication. SPIE uses a six-digit CID article numbering system structured as follows:

- The first five digits correspond to the SPIE volume number.

- The last two digits indicate publication order within the volume using a Base 36 numbering system employing both numerals and letters. These two-number sets start with $00,01,02,03,04,05$, $06,07,08,09,0 A, 0 B \ldots$ OZ, followed by 10-1Z, 20-2Z, etc. The CID Number appears on each page of the manuscript. 


\title{
Contents
}

\author{
$\checkmark \quad$ Authors \\ vii Conference Committee
}

\section{HIGH PERFORMANCE COMPUTING I}

1000702 A new tool for supervised classification of satellite images available on web servers: Google Maps as a case study (Best Student Paper Award) [10007-1]

1000703 A study on computation optimization method for three-dimension scene light field radiation simulation in visible light band [10007-2]

1000704 Increasing the object recognition distance of compact open air on board vision system [10007-3]

1000705 Performance of the dot product function in radiative transfer code SORD [10007-4]

HIGH PERFORMANCE COMPUTING II

1000707 Parallel hyperspectral image reconstruction using random projections [10007-6]

1000708 A new semi-supervised classification strategy combining active learning and spectral unmixing of hyperspectral data [10007-7]

1000709 Parallel implementation of a hyperspectral image linear SVM classifier using RVC-CAL [10007-8]

10007 OA The implementation of contour-based object orientation estimation algorithm in FPGAbased on-board vision system [10007-9]

10007 OB OpenCL-library-based implementation of SCLSU algorithm for remotely sensed hyperspectral data exploitation: CIMAGMA versus viennaCL [10007-10]

HIGH PERFORMANCE COMPUTING III

10007 OC A multiple criteria-based spectral partitioning method for remotely sensed hyperspectral image classification [10007-11]

10007 OD A new comparison of hyperspectral anomaly detection algorithms for real-time applications [10007-12]

10007 OF A new hyperspectral image compression paradigm based on fusion [10007-14]

10007 OG Toward an optimisation technique for dynamically monitored environment [10007-15] 
HIGH PERFORMANCE COMPUTING IV

$10007 \mathrm{OH} \quad$ Parallelism exploitation of a PCA algorithm for hyperspectral images using RVC-CAL [10007-16]

10007 OK Spatial-spectral preprocessing for endmember extraction on GPU's [10007-20]

POSTER SESSION

10007 OM Fast DPCM scheme for lossless compression of aurora spectral images [10007-22]

10007 ON Generation of OAM waves using metamaterials substrate antenna [10007-23]

1000700 Hardware design and implementation of fast DOA estimation method based on multicore DSP [10007-24]

10007 OP Coastline change mapping using a spectral band method and Sobel edge operator [10007-25] 


\section{Authors}

Numbers in the index correspond to the last two digits of the six-digit citation identifier (CID) article numbering system used in Proceedings of SPIE. The first four digits reflect the volume number. Base 36 numbering is employed for the last two digits and indicates the order of articles within the volume. Numbers start with 00, 01, 02, 03, 04, 05, 06, 07, 08, 09, 0A, 0B...0Z, followed by 10-1Z, 20-2Z, etc.

Akopov, Eduard, 04
Al-Mansoori, Saeed, OP
Al-Marzouqi, Fatima, OP
Alpatov, Boris, OA
Babayan, Pavel, OA
Berdnikov, Vadim, 04
Bernabé, Sergio, OB
Botella, Guillermo, OB
Callicó, G. M., 09
Chen, Zengping, 0O
Desnos, K., OH
Díaz, María, OD
Dmitriev, Vladimir, 04
Dópido, Inmaculada, 08
Elyutin, Aleksey, 04
Ershov, Maksim, OA
Fabelo, H., 09
García-Flores, Agustín, 02
Guerra, Raúl, OF
Guo, Rui, 0O
Holben, Brent, 05
Jimenez, Luis I., OK
Juárez, E., 09, OH
Kirillov, Sergey, 04
Kong, Wanqiu, OM
Korkin, Sergey, 05
Kostkin, Ivan, 04
Lazcano, R., 09, OH
Li, Jun, O2, 08, OC, OK
Li, Ligang, 03
Lin, Qianqiang, 00
Liu, Yi, 08, 0C
López, Sebastián, OD, OF
Lyapustin, Alexei, 05
Ma, Xiaoshan, 03
Madroñal, D., 09, OH
Martín, Gabriel, 07
Melián, José, OF
Meng, X. S., ON
Meng, Xin, 03
Nascimento, José M. P., 07
Navarro, José M. R., OB
Ni, Wei, O3
Orueta, Carlos, OB
Paz-Gallardo, Abel, 02
Pelcat, M., OH
Plaza, Antonio, 02, 08, OB, 0C, OK
Plaza, Javier, OK

Qu, T., ON

Sanz, C., 09, $\mathrm{OH}$

Sarmiento, Roberto, OD, OF

Sevilla, Jorge, 07

Shen, Feifei, 03

Shurrab, Orabi M., OG

Sidrach-Cardona, I., $\mathrm{OH}$

Sinyuk, Aliaksandr, 05

Strotov, Valery, 04, 0A

Sun, Yanli, 08, 0C

Wu, Jaiji., OM, ON

Wu, Z. S., ON

Yang, Zhen, 03

Zhang, Xia, 08

Zhang, Yue, 00

Zhao, Yingxiao, 00

Fabelo, H., 09

Guerra, Raúl, OF

Kong, Wanqiu, OM

Korkin, Sergey, 05

ostkin, Ivan, 04

Li, Jun, 02, 08, OC, OK

Li, Ligang, 03

Lianqiang, 00

López, Sebastián, OD, OF

Lyapustin, Alexei, 05

Ma, Xiaoshan, 03

Nascimento, José M. P., 07

Navarro, José M. R., OB

$\mathrm{Ni}, \mathrm{Wei}, 03$

Paz-Gallardo, Abel, 02

Pelcat, M., OH

Plaza, Javier, OK

Prieto-Matías, Manuel, OB 
Proc. of SPIE Vol. 10007 1000701-6

Downloaded From: https://www.spiedigitallibrary.org/conference-proceedings-of-spie on 26 Apr 2023 Terms of Use: https://www.spiedigitallibrary.org/terms-of-use 


\section{Conference Committee}

Symposium Chair

Klaus Schäfer, (Retired) Karlsruhe Institute of Technology, Institute of Meterology and Climate Research (Germany)

Symposium Co-chairs

Christopher M. U. Neale, University of Nebraska-Lincoln

(United States), Daugherty Water for Food Institute (United States)

Iain H. Woodhouse, The University of Edinburgh (United Kingdom),

Geography and the Lived Environment Research Institute

(United Kingdom)

Conference Chairs

Bormin Huang, University of Wisconsin-Madison (United States)

Sebastián López, Universidad de Las Palmas de Gran Canaria (Spain)

Zhensen Wu, Xidian University (China)

Conference Co-chairs

Jose M. Nascimento, Instituto de Telecomunicações (Portugal)

Jun Li, Sun Yat-Sen University (China)

Valeriy V. Strotov, Ryazan State Radio Engineering University

(Russian Federation)

Conference Program Committee

Saeed H. Al-Mansoori, Emirates Institution for Advanced Science and Technology (United Arab Emirates)

Boris A. Alpatov, Ryazan State Radio Engineering University

(Russian Federation)

Chein-I Chang, University of Maryland, Baltimore County

(United States)

Yang-Lang Chang, National Taipei University of Technology (Taiwan)

Mingmin Chi, Fudan University (China)

Qian Du, Mississippi State University (United States)

Dustin Feld, Universität zu Köln (Germany)

Carlos E. Garcia Gonzalez, Universidad Complutense de Madrid (Spain)

Lixin Guo, Xidian University (China)

Eduardo Juarez, Universidad Politécnica de Madrid (Spain)

Francesco Leporati, Università degli Studi di Pavia (Italy) 
Qiguang Miao, Xidian University (China)

Caner Özcan, Karabük Üniversitesi (Turkey)

Enrique S. Quintana-Orti, Universidad Jaume I (Spain)

Jarno Mielikainen, University of Wisconsin-Madison (United States)

Antonio J. Plaza, Universidad de Extremadura (Spain)

Sergio Sanchez Martinez, Masdar Institute of Science \& Technology (United Arab Emirates)

Roberto Sarmiento, Universidad de Las Palmas de Gran Canaria (Spain)

Yuliya Tarabalka, INRIA Sophia Antipolis - Méditerranée (France)

Carole Thiebaut, Center National d'Études Spatiales (France)

Tanya Vladimirova, University of Surrey (United Kingdom)

Shih-Chieh Wei, Tamkang University (Taiwan)

Jiaji Wu, Xidian University (China)

Yuanfeng Wu, Institute of Remote Sensing and Digital Earth (China)

\section{Session Chairs}

1 High Performance Computing I

Bormin Huang, University of Wisconsin-Madison (United States)

2 High Performance Computing II

Sebastián López, Universidad de Las Palmas de Gran Canaria (Spain)

3 High Performance Computing III

José M. Nascimento, Instituto de Telecomunicações (Portugal)

4 High Performance Computing IV

Valeriy V. Strotov, Ryazan State Radio Engineering University

(Russian Federation) 